\title{
Journal of Civil Engineering, Science and Technology
}

Volume 9, Issue 1, April 2018

\section{SEISMIC PERFORMANCE OF DAMPER INSTALLED IN HIGH-RISE STEEL BUILDING IN BANGLADESH}

\author{
T.Tabassum ${ }^{1}$ and K.S. Ahmed ${ }^{2}$ \\ ${ }^{1}$ Lecturer, Department of Civil Engineering, Ahsanullah University of Science and Technology, 142-142 Love Road, \\ Tejgaon Industrial Area, Dhaka 1208, Bangladesh \\ ${ }^{2}$ Associate Professor, Department of Civil Engineering, Military Institute of Science and Technology, Mirpur Cantonment, \\ Dhaka 1216, Bangladesh
}

Date received: 03/01/2018, Date accepted: 02/04/2018

Corresponding authors' emails: saki10104@gmail.com, tanzilalita99@yahoo.com

\begin{abstract}
This research paper describes the results of analysis of the seismic behavior of a thirty story steel building with and without damper under different earthquake acceleration signals. The proposed procedure placed the various types of damper like friction damper, bilinear damper and exponential damper on the top three floors of the building. The study compares the different performances such as the joint displacement, joint acceleration, the base force of structure with and without damper for a thirty-story steel building using ETAB2015. The study further performs time history analysis for different seismic accelerograms to observe the actual time domain responses of the structure. Linear time-history analysis on this steel building structure indicates that maximum displacement, maximum base force, and maximum acceleration effectively reduce in the presence of damper at top three floors of the building.
\end{abstract}

Copyright () 2018 UNIMAS Publisher. This is an open access article distributed under the Creative Commons Attribution-NonCommercial-ShareAlike 4.0 International License which permits unrestricted use, distribution, and reproduction in any medium, provided the original work is properly cited.

Keywords: Earthquake, damper, static pushover analysis, linear time history, demand and capacity spectrum

\subsection{INTRODUCTION}

Over the last few decades, the world has experienced numerous devastating earthquakes. As a result, due to the collapse of buildings and severe structural damages in densely populated areas, an increased loss of human life occurred. In developed societies with modern infrastructure, major earthquakes claim significantly fewer lives when compared to prior generations. Our understanding of earthquake mechanisms and seismic ground motions is continually advancing. Furthermore, the understanding of how buildings respond to earthquakes continues to enhance. Recent studies give more importance to the research and development of structural control techniques such as passive control system, active control system, and semi-active control system giving particular importance to the improvement of seismic responses of buildings. Passive control systems do not require any power supply. For the typical design of building against earthquake, resistant of the building stems from the stiffness, ductility, and structural damping, thus, large amounts of energy dissipate through localized damage or plastic hinges formed in the lateral resistant system [1,2]. Energy dissipation action in a frame system, such as beam and column in a moment- resisting frame produces damage in those components. Repair of such damage after an earthquake is very expensive and often requires evacuation of the building. By locating energy dissipation device to new and existing structures earthquake-induced energy can dissipate efficiently. This enhanced structural system can reduce damage to the structures. Energy-induced by the earthquake can disperse by adding additional equipment called damper. Dr. Johannes Calantarients proposed the first seismic isolation system (damper), an English medical doctor, in the year 1909 [7]. His theory showed that if a building could be separated from its foundation by a layer of talc, it would isolate the main structure from seismic shock [17]. Damper, a device useful as a seismic retrofit or strengthening in new construction, dissipates a significant portion of the induced energy in the most critical parts, so damage to the structure minimizes [4,5]. Among the three structural control systems referred in the preceding portion, damper system belongs to the passive control group. There are various types of dampers such as a viscous damper, tuned mass damper, friction, bilinear and exponential damper [3,615]. Among this dampers, exponential, bilinear, friction dampers act as a function of displacement. In Bangladesh, the practice of application of energy dissipation device in existing or new buildings is still 
at an early stage. This paper intends to focus on the advantages of nonlinear mass damping devices $[2,10]$. Nonlinear time history analysis is of paramount importance for seismic analysis and performance study. This research paper presents the nonlinear time history analysis of thirty story steel building frame with and without damper considering S-Monica2, Altadena, Corralit earthquake acceleration signals. The damper proves to be a significant device in enhancing the seismic performance of a building. Current investigation supports the conclusion by proving the contribution of the damper in the reduction of the story displacement, base shear, and joint acceleration while increasing the natural period of the structure.

\subsection{METHODOLOGY}

The study focuses on the seismic behavior of a 30-story 3D steel frame. Several researchers reported various aspects of damper enhanced structures including linear and nonlinear static and linear and nonlinear dynamic analysis of buildings frames fitted with dampers. This study locates the damper in top three floors for to enhance its seismic behavior. A comparison of time history analysis with and without damper compares the significant parameters such as story displacements, joint acceleration, and base shear.

\subsection{MODELING AND ASSUMPTIONS}

Structural system analyzed in this paper is a steel frame structure. The building has 13 bay in the $\mathrm{X}$ direction and eight bay in Y direction [Figs. 1 and 2], and the height of the building is $305 \mathrm{ft}$. The damper locates in $30^{\text {th }}, 29^{\text {th }}$, and $28^{\text {th }}$ storey. The current study employs a two-dimensional plane frame to study the seismic behavior of the structure assuming the seismic responses in two perpendicular directions to be independent of each other. Table 1 shows the building materials, loads and properties of frame as well as area sections.

Table 1 Building materials and properties

\begin{tabular}{lc}
\hline Name of structural member and loads & Specification \\
\hline Bays in X direction & 13 \\
Bays in Y directions & 8 \\
Typical story height (ft) & 10 \\
Bottom tory height (ft) & 15 \\
Typical beams & W 27 x 102 (A- LatBm) \\
Grade beam & W 27 x 102 (A- LatBm) \\
Typical Columns & W 14 x 193 (A- LatBm) \\
Slab thickness (inch) & 8 \\
Compressive strength of concrete (psi) & 4000 (for all) \\
Grade of steel (ksi) & 50 \\
Grade of rebar (ksi) & 60 \\
Dead load (psf) & 75 \\
Live load (psf) & 60 \\
Auto Mesh type & At points / lines / edges \\
Joint assignment- Restrain & Fixed support \\
\hline
\end{tabular}

\subsection{DAMPER MODELING}

This study simulates and compares the effect of exponential, bilinear, and friction dampers on the seismic performance of the structure. This paper presents nonlinear time history analyzes of the structure using ETABS 2015, a nonlinear finite element based structural analysis software. 


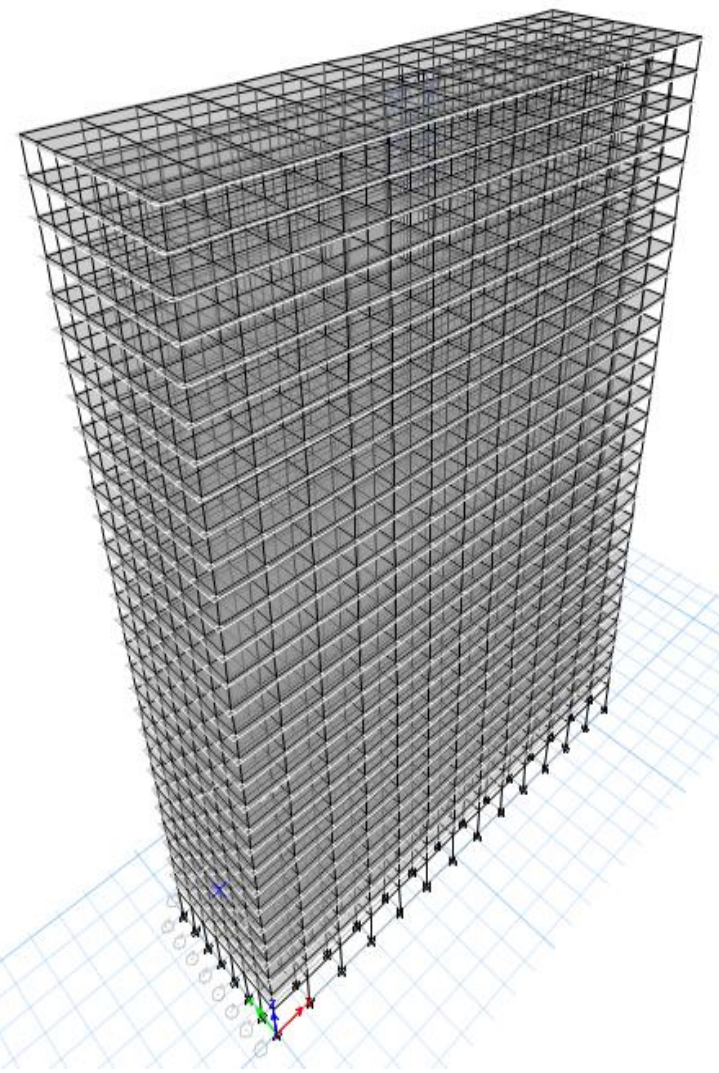

Figure $13 d$ view of model

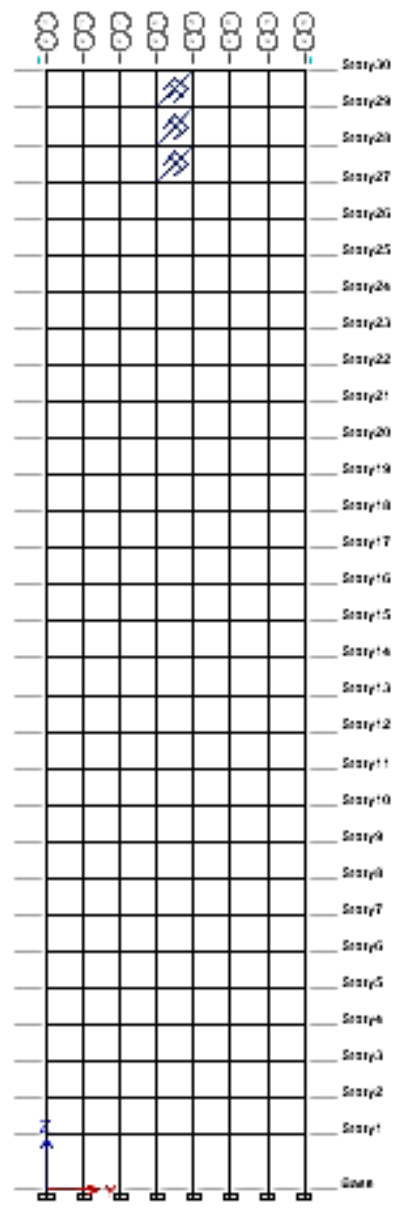

Figure 2 Elevation of model

Figure 1 and Figure 2 illustrate the 3D view and elevation of 30-story steel frame structure respectively.

Table 2 Damper properties

\begin{tabular}{lccc}
\hline \multicolumn{1}{c}{ Properties } & Exponential & Bilinear & Friction Spring \\
\hline Mass(lb-s'st) & 73454.1 & 73454.1 & 73454.1 \\
Weight (kip) & 1301.70 & 1301.70 & 1301.70 \\
Effective stiffness(kip/in) & 666.5 & 666.5 & 666.5 \\
Effective Damping(kip-s/in) & 216.82 & 216.82 & 216.82 \\
Stiffness(kip/in) & 1000 & 1000 & 1000 \\
$\begin{array}{l}\text { Damping coefficient } \\
\text { (kip-s/in) }\end{array}$ & 271.02 & - & - \\
Damping Exponent & 1 & - & - \\
Initial Damping coefficient(kip-s/in) & - & 1212.056 & - \\
$\begin{array}{l}\text { Yielded Damping coefficient } \\
\text { (kip-s/in) }\end{array}$ & - & & - \\
\hline
\end{tabular}




\begin{tabular}{lccc}
\hline Linear Force Limit (kip) & - & 0.001 & - \\
$\begin{array}{l}\text { Slipping Stiffness(loading) } \\
\text { (kip/in) }\end{array}$ & - & - & 1200 \\
Slipping stiffness (unloading) (kip/in) & - & - & 1000 \\
Stop displacement(in) & - & - & 0 \\
\hline
\end{tabular}

\subsection{RESULT AND DISCUSSION}

Figures 3 to 6 illustrate the findings from the time history analysis of the 30 story building steel frame structure with mass damper. Table 3 to 8 lists the values in the form of the period, moment, and shear value for EQY and WINDY of building frames, base shear or force and base acceleration; story displacement. The investigation observed that there is significant variation in results due to the different earthquake motions [3]. As different time histories has different time periods and peak accelerations, here only 3 types of time histories (S- Monica2, Altadena and Corralit) have been used. The other earthquakes behave more or less same as these three earthquakes.

\subsection{MODE NUMBERS WITH PERIOD}

For various mode numbers and shapes, the natural period of the building increase with the installation of dampers in the frame. In this regard, exponential dampers work more efficiently, and bilinear damper along with friction spring damper [8,9] display more or less the same natural period. The reasoning is that as the mass of the building increases, the period also increased according to the following equation. This is because damper essentially dissipates energy and delays the motion so the time taken to complete one cycle increases slightly. As the time period of the building increases for different dampers from without damper of the building, the building structure gets more time for dissipating energy of the shock.

$$
\mathrm{T}=(2 \times \pi \times \sqrt{\mathrm{m}}) \div(\sqrt{\mathrm{k}})
$$

Here, $m=$ mass of damper

$\mathrm{k}=$ stiffness of damper

Table 3 represents the increment of the period for different mode shapes. The increase of building period varies from four to ten percentages.

Table 3 Increment of building period

\begin{tabular}{ccccc}
\hline Modal number & $\begin{array}{c}\text { Time period } \\
(\mathrm{sec})\end{array}$ & $\begin{array}{c}\text { Time period(sec) } \\
\text { Without damper }\end{array}$ & $\begin{array}{c}\text { Time period } \\
\text { Expontial damper }\end{array}$ & $\begin{array}{c}\text { Time Period (sec) } \\
\text { Friction damper }\end{array}$ \\
\hline 1 & 4.321 & 4.949 & 4.949 & 4.947 \\
2 & 3.784 & 3.806 & 3.806 & 3.806 \\
3 & 3.126 & 3.525 & 3.525 & 3.523 \\
4 & 1.394 & 1.526 & 1.526 & 1.523 \\
5 & 1.234 & 1.239 & 1.239 & 1.239 \\
6 & 1.029 & 1.126 & 1.126 & 0.805 \\
7 & 0.754 & 0.805 & 0.805 & 0.696 \\
8 & 0.694 & 0.696 & 0.696 & 0.634 \\
9 & 0.597 & 0.636 & 0.636 & 0.547 \\
10 & 0.523 & 0.549 & 0.549 & 0.521 \\
11 & 0.421 & 0.521 & 0.521 & 0.486 \\
13 & 0.415 & 0.486 & 0.486 & 0.439 \\
14 & 0.324 & 0.44 & 0.44 & 0.413 \\
\hline
\end{tabular}




\begin{tabular}{ccccc}
\hline 16 & 0.238 & 0.336 & 0.336 & 0.337 \\
17 & 0.218 & 0.309 & 0.309 & 0.311 \\
18 & 0.187 & 0.276 & 0.276 & 0.28 \\
19 & 0.164 & 0.27 & 0.27 & 0.26 \\
20 & 0.146 & 0.229 & 0.229 & 0.224 \\
21 & 0.129 & 0.194 & 0.194 & 0.191 \\
22 & 0.109 & 0.16 & 0.16 & 0.158 \\
23 & 0.087 & 0.124 & 0.124 & 0.123 \\
24 & 0.066 & 0.087 & 0.087 & 0.086 \\
25 & 0.034 & 0.038 & 0.038 & 0.037 \\
\hline
\end{tabular}

\subsection{MOMENT AND SHEAR VALUE}

Moment and base shear value of analyzed building frames increase if dampers locate on the involved frames. Thus, this study only investigates elevation $45 \mathrm{GG}$ frames and load cases EQY and WINDY. Table 4 illuminates the percentages of the maximum increase in shear and moment values for the 45GG frame. Installing damper is the indication of increasing the total mass of the building. So, the ultimate moment and shear force value of those (where dampers are installed) frames increases. Moment in 3-3 direction as well as shear in 2-2 direction are showed in the figures and those are the local axis directions of the frame cross section.

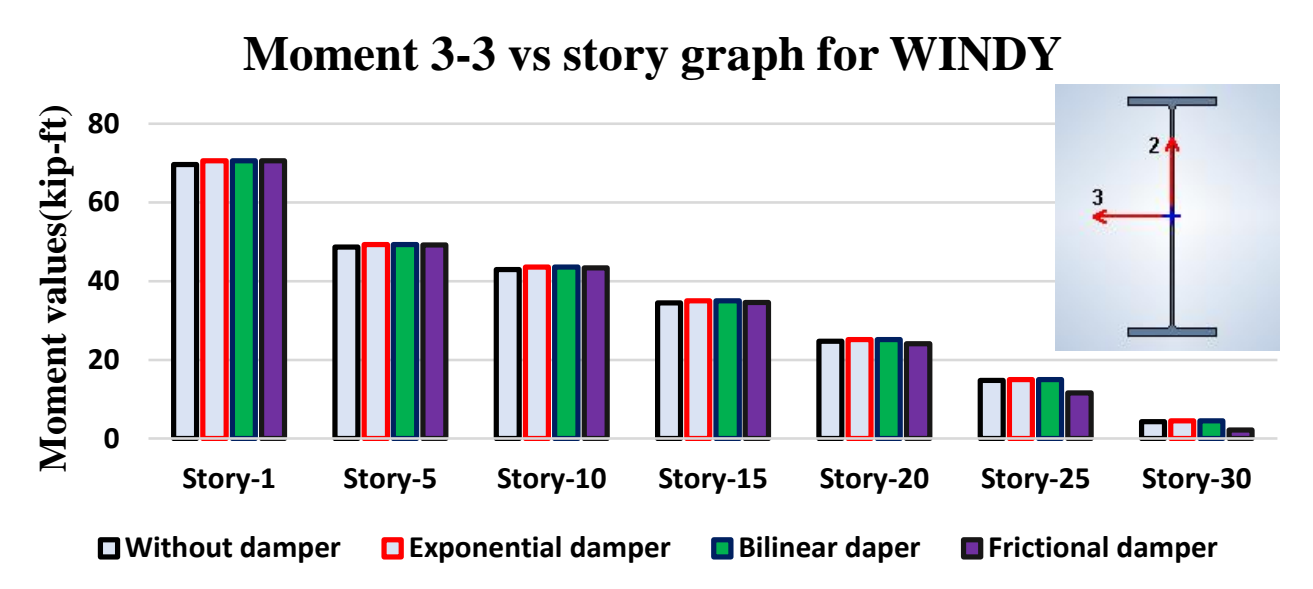

Figure 3 Moment values for WINDY

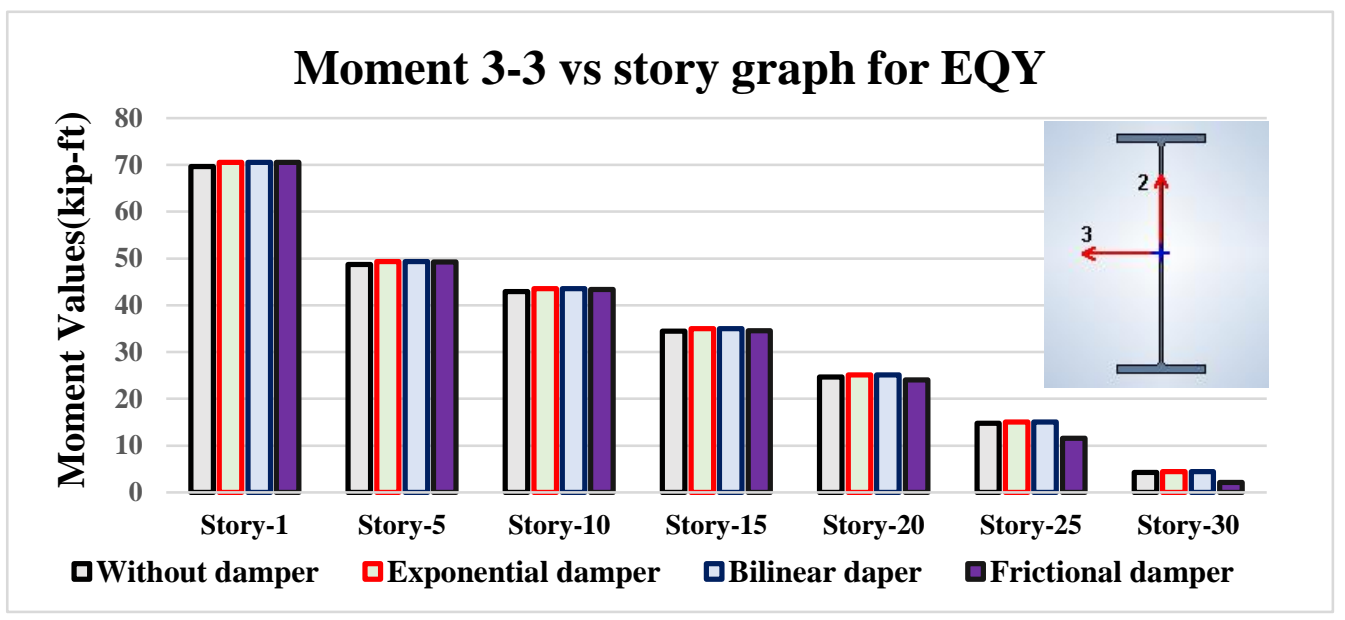

Figure 4 Moment values for EQY 


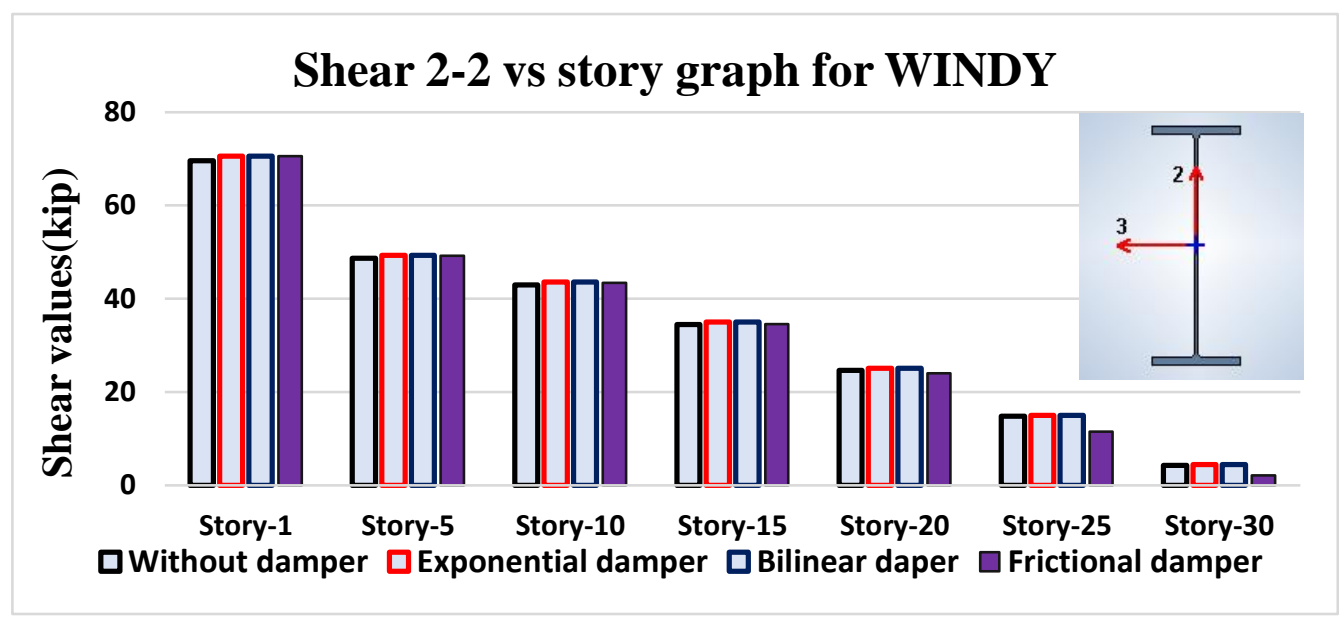

Figure 5 Shear values for EQY

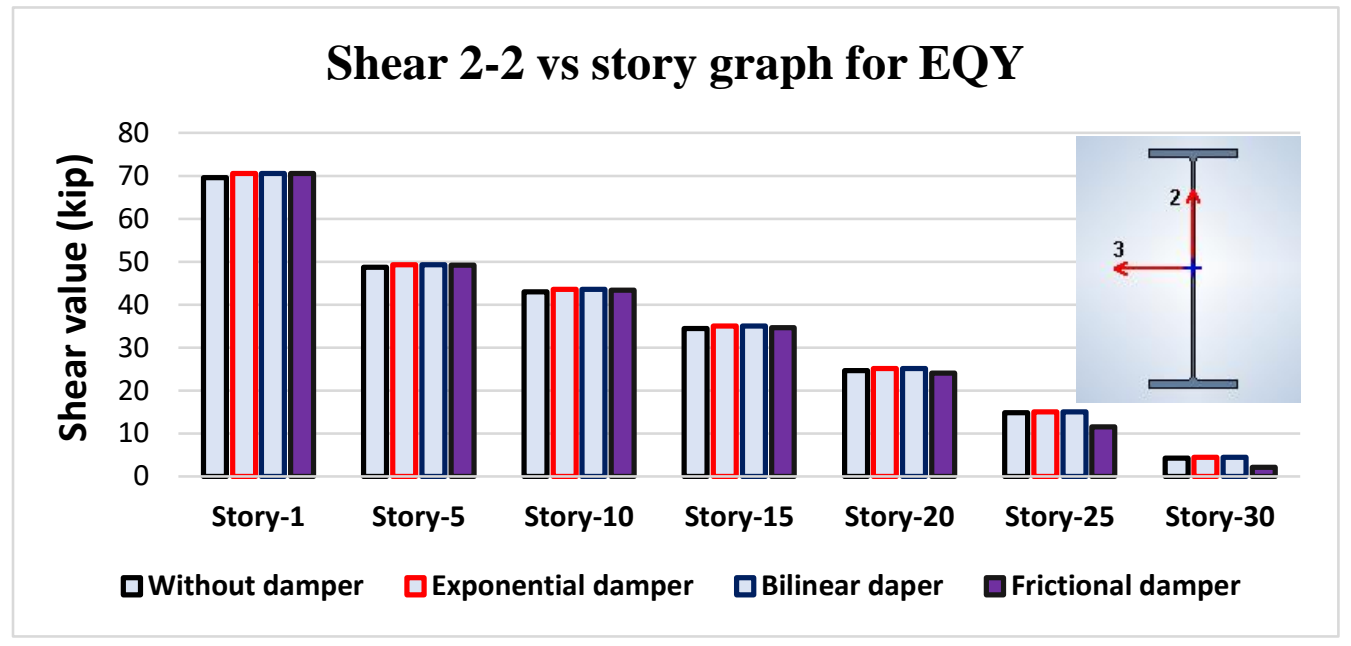

Figure 6 Shear values for WINDY

As moment and shear values of the frames are increased, these lead engineers to design those frames for more allowable capacity and thus ensures security and durability.

Table 4 Moment and shear value

\begin{tabular}{cccccc}
\hline Kind of Response & $\begin{array}{c}\text { Without } \\
\text { Damper }\end{array}$ & $\begin{array}{c}\text { Bilinear } \\
\text { Damper }\end{array}$ & $\begin{array}{c}\text { Percent } \\
\text { Increased \% }\end{array}$ & $\begin{array}{c}\text { Friction } \\
\text { Dampers }\end{array}$ & $\begin{array}{c}\text { Percent Increased } \\
\%\end{array}$ \\
\hline Moment (kip-ft) EQY & 121.855 & 140.07 & 14.95 & 139.955 & 14.85 \\
Moment (kip-ft) WINDY & 302.531 & 306.61 & 1.34 & 306.513 & 1.32 \\
Shear (kip) EQY & 28.04 & 32.232 & 14.95 & 32.205 & 14.85 \\
Shear (kip) WINDY & 69.61 & 70.549 & 1.34 & 70.568 & 1.32 \\
\hline
\end{tabular}




\subsection{TIME HISTORY ANALYSIS OF BUILDING FRAME}

ETABS is an FE-based structural design and analysis software. The current research utilizes ETABS 2015 to analyze a thirty-story building frame to study its seismic performance with and without a damper under both linear and nonlinear time history analysis.

\subsubsection{RESIDUAL DRIFT}

Residual drift is very threatening for a building as it is the permanent deformations that remain after the earthquake. Installation of dampers at the top portion of the building can successfully reduce the residual drift. As damper absorps energy, the ultimate residual drift is decreased. Table 5 and figure 7 demonstrate that the residual drift decreases after the installation of the damper, and it becomes almost zero for the exponential damper.

Table 5 Residual drift for S_Monica2

\begin{tabular}{ccc}
\hline Dampers & Residual Drift*100 & Percent Reduction $(\%)$ \\
\hline Without Damper & 0.023556 & 99.63 \\
Exponential Damper & 0.0000856 & 99.12 \\
Bilinear Damper & 0.0002076 & 98.268 \\
Friction Spring Damper & 0.0004079 & \\
\hline
\end{tabular}

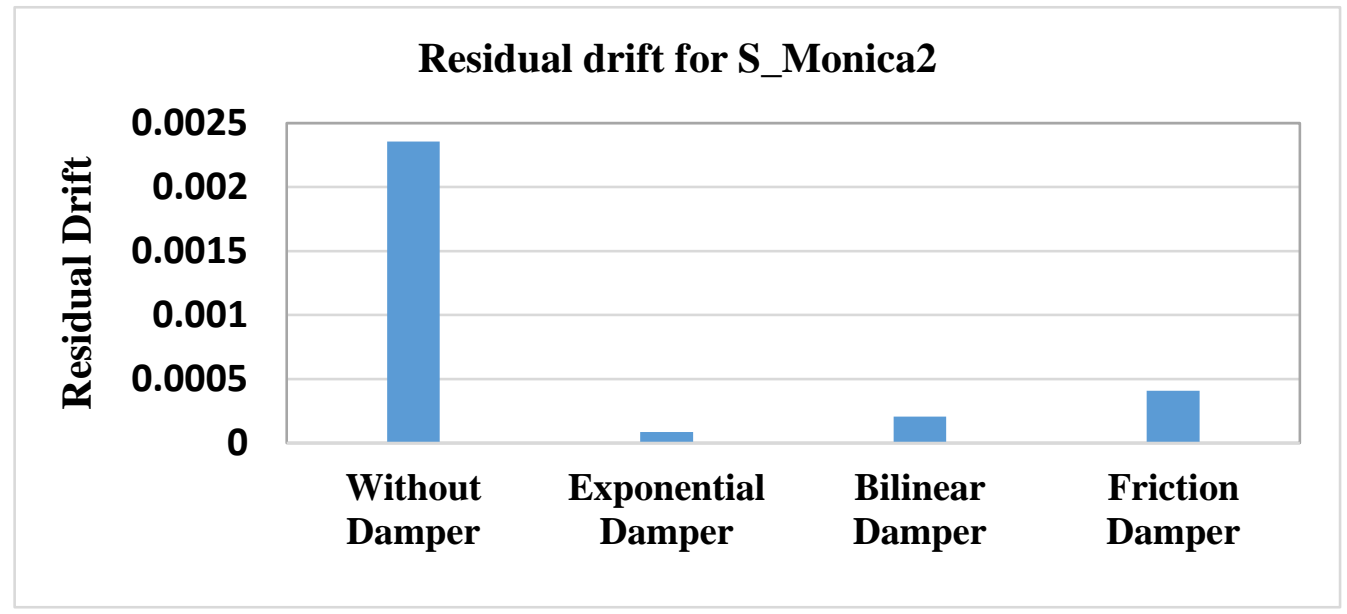

Figure 7 Residual drift for S_Monica2

\subsubsection{MAXIMUM BASE SHEAR OR FORCE}

Base shear is another important parameter in deriving the response of the frame against earthquake. Base shear may increase or decrease depending on the geometry of the structure. Mainly, for high rise buildings, base shear decreases whereas for low rise buildings, after installing dampers base shear increases [18]. 


\begin{tabular}{|c|c|c|c|c|}
\hline \multirow[b]{2}{*}{ EQ } & \multirow[b]{2}{*}{ Without Damper (kip) } & \multicolumn{3}{|c|}{$\begin{array}{l}\text { Base Reaction With Damper } \\
\text { (Kip) }\end{array}$} \\
\hline & & $\begin{array}{l}\text { Exponential } \\
\text { Damper }\end{array}$ & Bilinear Damper & $\begin{array}{c}\text { Friction Spring } \\
\text { Damper }\end{array}$ \\
\hline S_Monica2 & 1565.612 & 1377.396 & 1315.1 & 1376.8 \\
\hline Altadena & 3199.046 & 3063.848 & 3016.7 & 3087.70 \\
\hline Corralit & 1951.22 & 1950.22 & 1897.0 & 1951.01 \\
\hline
\end{tabular}

Figure 8 illustrates that the base forces are minimum and almost equal for the exponential damper and friction spring damper and slightly smaller for bilinear damper compared to the other two.

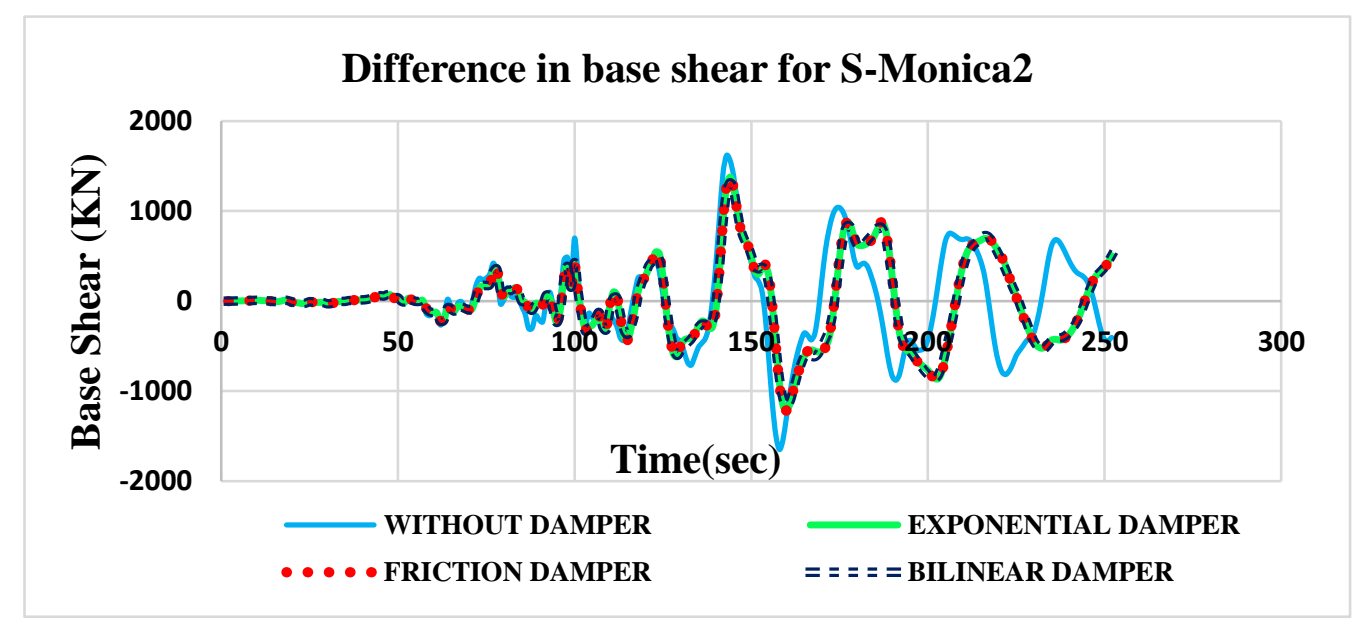

Figure 8 Base shear for different dampers

\subsubsection{MAXIMUM JOINT ACCELERATION}

Joint acceleration of 30 story steel frame structure decreases when the damper locates on top three floors for all three-earthquake accelerograms namely, EQ S_Monica2, EQ Altadena, and EQ Corralit load. Table 7 represents the reduction of top floor joint (number 60) acceleration for different earthquake load case when dampers locate in the building compared to the frames without a damper. Joint acceleration reduces more significantly for EQ Corralit. As damper dissipates the seismic shock, the joint acceleration also decreases. 


\begin{tabular}{ccccc}
\hline & & \multicolumn{3}{c}{$\begin{array}{c}\text { Joint Acceleration With Damper } \\
\left(\mathrm{in} / \mathrm{sec}^{2}\right)\end{array}$} \\
\cline { 3 - 5 } EQ & $\begin{array}{c}\text { Wamper } \\
(\text { in/sec }\end{array}$ & Bilinear Damper & $\begin{array}{c}\text { Friction Spring } \\
\text { Damper }\end{array}$ \\
\cline { 3 - 5 } & 164.536 & 164.235 & 164.21 & 164.235 \\
S_Monica2 & 502.4486 & 501.387 & 501.36 & 501.981 \\
Altadena & 198.267 & 188.193 & 177.9 & 188.034 \\
Corralit & & & $\begin{array}{c}\text { Exponential } \\
\text { Damper }\end{array}$ & \\
\hline
\end{tabular}

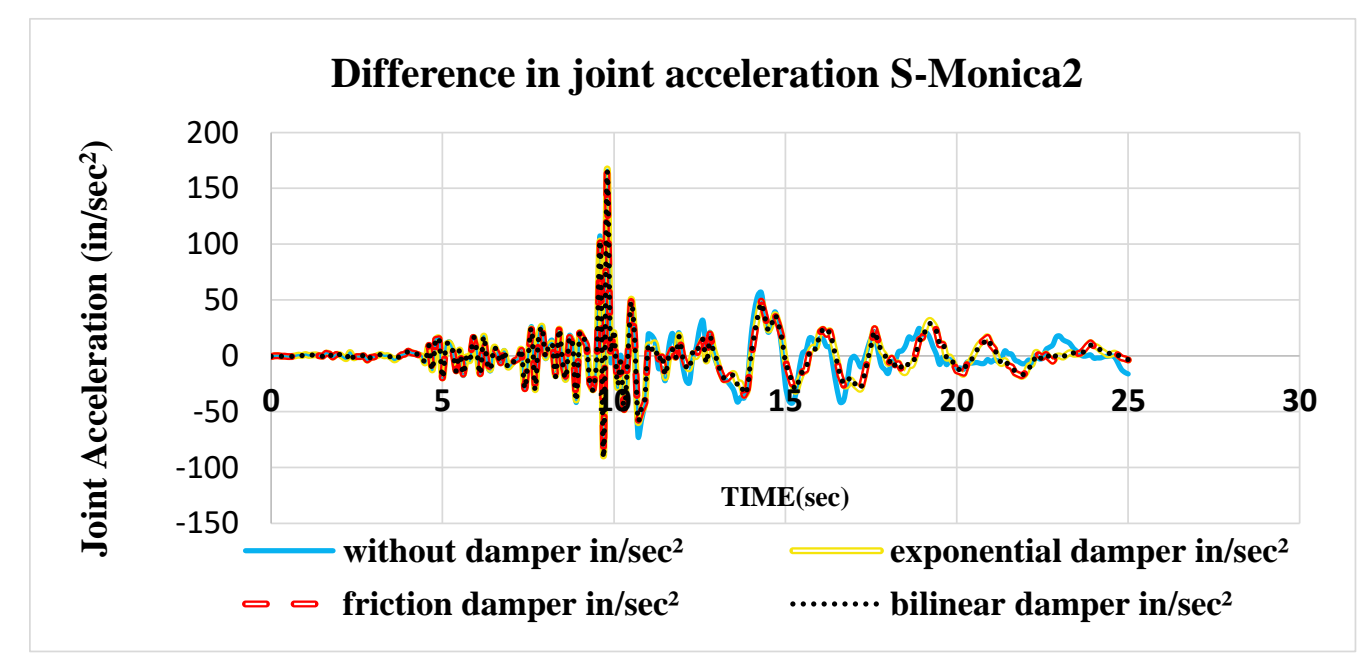

Figure 9 Joint acceleration for different damper

This study extracts from Figure 9 that the installation of mass dampers decrease the joint acceleration for the three earthquakes and are shown in Table 7.

\subsubsection{MAXIMUM JOINT DISPLACEMENT}

Table 8 represents that the reduction of top floor joint (number 60) displacement for various earthquake load case when dampers provided in the building compares to the frame without a damper. However, here an interesting result is observed. For EQ S_Monica2, joint displacement is increased but for Altadena and Corralit EQ, joint displacement is decreased. This is because, EQ S_Monica has larger amplitude and intensity than the other two earthquakes.

Table 8 Joint displacement

\begin{tabular}{|c|c|c|c|c|}
\hline \multirow{2}{*}{ EQ } & \multirow{2}{*}{ WO Damper(in) } & \multicolumn{3}{|c|}{$\begin{array}{l}\text { Joint Displacement With Damper } \\
\text { (in) }\end{array}$} \\
\hline & & $\begin{array}{l}\text { Exponential } \\
\text { Damper }\end{array}$ & Bilinear Damper & $\begin{array}{l}\text { Friction Spring } \\
\text { Damper }\end{array}$ \\
\hline S_Monica2 & 5.717643 & 6.541009 & 6.4486 & 6.49356 \\
\hline Altadena & 6.468611 & 5.143085 & 4.97329 & 5.10152 \\
\hline Corralit & 8.487805 & 4.699361 & 4.74011 & 4.93359 \\
\hline
\end{tabular}




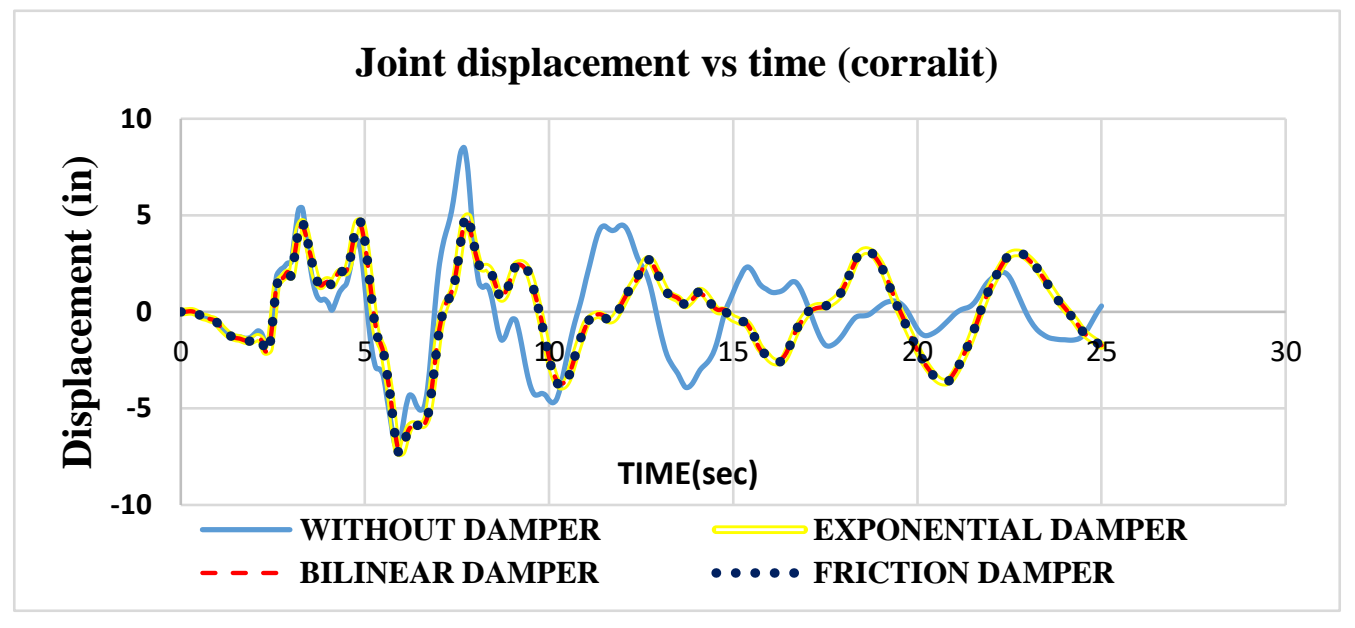

Figure 10 Joint displacement vs time for different dampers

\subsection{HYSTERESIS LOOP}

Energy dissipated by three types of dampers highlights in the graphs provided on the structure. Figure 11 shows that energy dissipation for bilinear damper is more for steel building than exponential and friction spring damper. Friction spring dampers are well within the elastic limit showing its linear behavior.

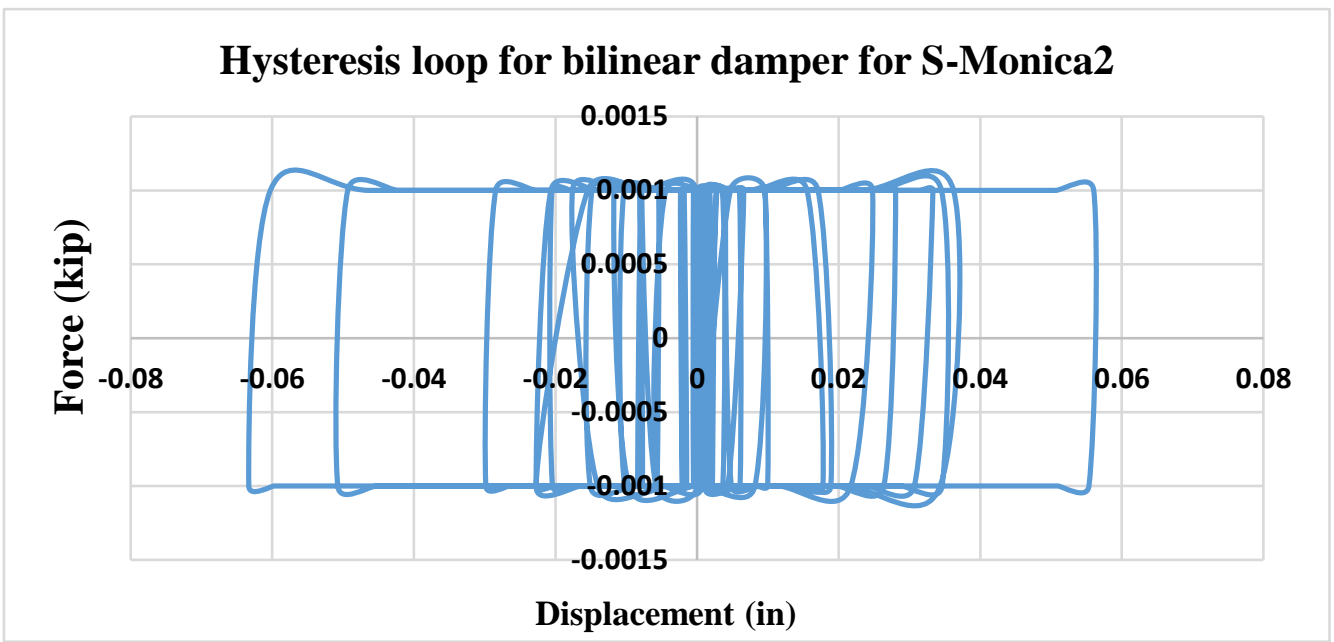

Figure 11 Hysteresis loop for bilinear damper 


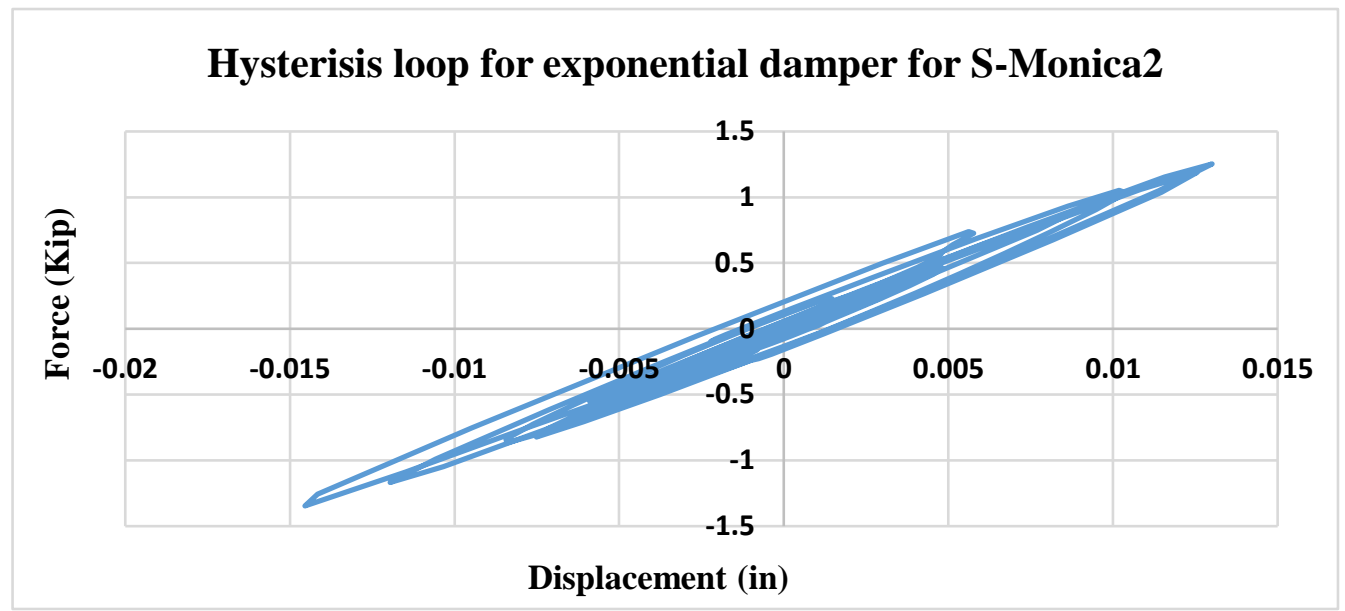

Figure 12 Hysteresis loop for exponential damper

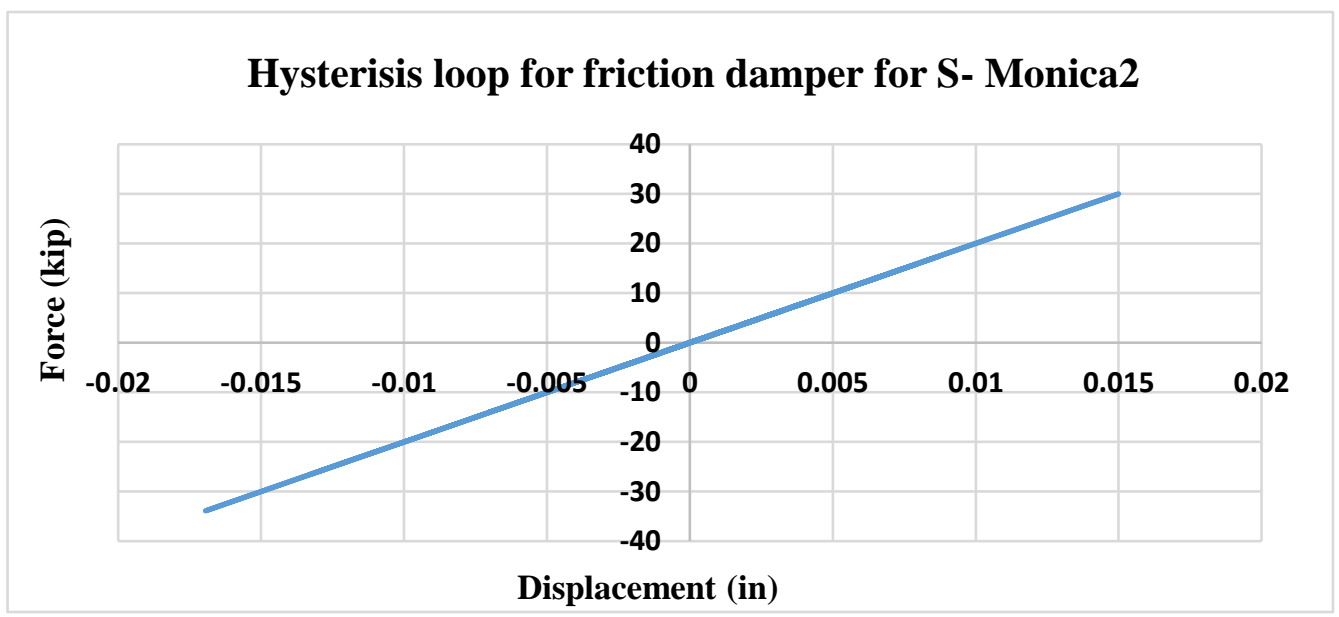

Figure 13 Hysteresis loop for friction spring damper

\subsection{CONCLUSION}

From the overall discussion and analysis of our study, we can come to the following recommendations:

1. Seismic performance of a building can improve by installing energy dissipating device (damper) as it absorbs and dissipate energy during an earthquake.

2. Base shear reduces effectively with the deployment of the damper.

3. Joint acceleration decreases in the presence of damper, so the inertia forces also reduces.

4. As the story displacement reduces, the structure requires less ductility to resist same earthquake forces. On the other hand, a typical building with limited ductility can withstand larger earthquake loads.

5. Seismic performance has been improved as the modal period increases beyond the typical site period in Bangladesh. 


\section{REFERENCES}

[1] Balakrishna G.S, J. Jacob. Seismic Analysis of Building Using Two Types of Passive Energy Dissipation Devices. IOSR Journal of Mechanical and Civil Engineering (IOSR-JMCE), e-ISSN: 2278-1684, p-ISSN: 2320-334X, PP 1319.

[2] Khan W., Dr. S. Akhtar, A. Hussain (2014). Non- linear time history analysis of tall structure for a seismic load using a damper. International Journal of Scientific and Research Publications, Volume 4, Issue 4, ISSN 2250-3153, April 2014.

[3] Lopez I., J.M. Busturia, H. Nijmeijer (2003). Energy dissipation of a friction damper. Journal of Sound and Vibration, 278 (2004) 539-561, October 2003.

[4] Purasinghe R. Seismic Evaluation and Retrofit of A Moment Frame Building With Viscous Dampers, Professor of Civil Engineering, California State University at Los Angeles, California.

[5] Rao S-S. Mechanical Vibrations. 5th-edition.

[6] Shaukat Khan Q, A. Ullah Case and M. Ilyas (2013). Improved Seismic Response of RC Frame Structures by Using Fluid Viscous Dampers. Pak. J. Engg. \& Appl. Sci., July 2013, Volume. 13, (p. 8-18).

[7] Saiful Islam A.B.M., M. Jameel, Md. A. Uddin, M. Zamin Jumaat (2012). Competent Building Elevation for Incorporating Base Isolation in Aseismic Structure. International Conference on Advances Science and Contemporary Engineering, ICASCE 2012.

[8] Thakur V.M and P.D. Pachpor (2012). Seismic Analysis of Multistoried Building with TMD (Tuned Mass Damper). International Journal of Engineering Research and Applications (IJERA), Volume 2, ISSN: 2248-9622, Issue 1, pp. 319-326.

[9] Wolff E. D., E C. Ipek, M. C. Constantinou and M. Tapan (2014). Effect of viscous damping devices on the response of seismically isolated structures. Published online in Wiley Online Library, DOI:10.1002/eqe.24643, 2014.

[10] Khan, W. (2014). Nonlinear time history analysis of tall structure for seismic load using damper. International Journal of Scientific and Research Publications, Volume 4, ISSN: 2250-3153, Issue 4.

[11] Heysami, A. (April 2015). Types of Dampers and their Seismic Performance During an Earthquake. Current World Environment. Volume 10 ,Special Issue 1, 1002-1015.

[12] Brock, J. E. (1946). A Note on the Damped Vibration Absorber. Journal of Applied Mechanics. ASME 13 , A-284.

[13] Kaynia, A. M. and Veneziano, D., Biggs, J. M. (1981). Seismic Effectiveness of Tuned Mass Dampers. Journal of the Structural Division. ASCE (107), 1465- 1484.

[14] Wong, K. F., and Johnson, J. G. (2009). Seismic Energy Dissipation of Inelastic Structures with Multiple Tuned Mass Dampers. Journal of Engineering Mechanics. 135(4), 265-275.

[15] Sladek, J. R., and Klingner, R. E. (1983). Effect of Tuned Mass Dampers on Seismic Response. Journal of Structural Engineering. ASCE (109), 2004-2009.

[16] Villaverde, R., and Aguirre, M., and Hamilton C. (2005). A seismic Roof Isolation System Built with Steel Oval Elements: Exploratory Study. Earthquake Spectra. Volume 21, No 1, pp. 225-241.

[17] http://www.masterbuilder.co.in/seismic-protection-systems/

[18] Chukwuma E., Kingsley C. O., Gregg E. B., Gary C. H. and Can S. The Benefits of Using Viscous Dampers in a 42Story Building 7 May 2010. 